\title{
Pengaruh Masuknya Budaya Populer terhadap Eksistensi Ajaran Sedulur sikep pada Masyarakat Samin
}

\author{
Ken Widyatwati \\ Fakultas Ilmu Budaya Universitas Diponegoro \\ Email: kenwidyatwati@gmail.com
}

\begin{abstract}
Klopoduwur Blora villagers are mostly descendants of Samin Surosentiko is a society that is still running the egalitarian values in daily life. These groups are known as community Samin. Samin community is a community that is consistent in behavior among others uphold the values of honesty, not envy, jealousy, prejudice is not ugly to others, behave and act what is ( not making this up ). Samin important for society not to disturb others and vice versa Samin people also do not want to disturb other people 's life and social institutions. Samin society is a society that can integrate the influx of popular culture with the attitude and teachings Sedulur sikep . Sedulur sikep teachings on society Samin persist accordance with the portions although popular culture spere entered public life Samin. In everyday life people Samin uphold the teachings Saminisme entrenched. Samin society trying to keep the existence and preserve the culture and teachings Sedulur sikep to instill and teach the younger generation descendants and tribes Samin.
\end{abstract}

Keywords : Samin community, the existence of the Sedulur sikep doctrine, popular culture.

\section{Intisari}

Penduduk desa Klopoduwur Blora yang sebagian besar keturunan Samin Surosentiko merupakan masyarakat yang masih menjalankan nilai-nilai yang egaliter dalam kesehariannya. Kelompok masyarakat ini dikenal sebagai masyarakat Samin. Masyarakat Samin adalah komunitas yang konsisten dalam berperilaku antara lain menjunjung tinggi nilai kejujuran, tidak iri, dengki, tidak berprasangka jelek pada orang lain, bersikap dan bertindak apa adanya (tidak mengada-ada). Bagi masyarakat Samin yang penting tidak mengganggu orang lain dan sebaliknya masyarakat Samin juga tidak mau orang lain mengganggu kehidupan dan pranata sosialnya. Masyarakat Samin merupakan masyarakat yang dapat memadukan masuknya budaya populer dengan sikap dan ajaran sedulur sikep. Ajaran sedulur sikep pada masyarakat samin tetap bertahan sesuai dengan porsinya walaupun kebudayaan populer masuk keranah kehidupan masyarakat Samin. Dalam kehidupan sehari-hari masyarakat Samin memegang teguh ajaran Saminisme yang sudah mengakar. Masyarakat Samin berusaha menjaga eksistensi dan memelihara kebudayaan serta ajaran sedulur sikep dengan menanamkan dan mengajarkan pada keturunan dan generasi muda suku samin.

Kata Kunci: Masyarakat Samin, eksistensi ajaran Sedulur sikep, budaya populer. 


\section{Pendahuluan}

Di masyarakat Jawa yang dianggap feodal terdapat sekelompok masyarakat yang mempunyai dan masih menjalankan nilai-nilai yang egaliter, yaitu masyarakat yang dikenal sebagai masyarakat Samin (Sedulur sikep). Menurut ajaran Saminisme orang harus rajin bekerja, mencintai alam semesta, jangan mencuri milik orang lain dan apabila ada seseorang minta sesuatu barang milik orang lain, maka orang itu wajib memberikan. Budaya Samin atau Saminisme sebagai sikap dan kepercayaan masyarakat memang tidak banyak memberi peluang untuk masuknya dan tumbuhnya budaya baru di masyarakat.

Orang Samin pada masa sekarang menganut agama yang disahkan pemerintah yaitu Islam, agar mereka sama seperti masyarakat lain yang bukan Samin, alasan pemilihan agama Islam seperti ini ternyata diikuti oleh anak-anak keturunan dari masyarakat Samin, mereka memilih agama Islam agar mereka sama dengan masyarakat pada umumnya walaupun masyarakat Samin tidak menjalankan ajaran agama Islam secara benar.

Berdasarkan uraian di atas maka, permasalahan dalam penelitian ini adalah bagaimana persepsi masyarakat Samin dan eksistensi ajaran sedulur sikep terhadap berkembangnya budaya populer di Desa Klopoduwur, Kecamatan Banjarejo, Kabupaten Blora.

Clifford Geetz, berpendapat bahwa dalam masyarakat Jawa terdapat tiga sub kebudayaan yaitu santri, abangan, priyayi. Sementara itu, Hildred Greetz, mengelompokkan masyarakat kepada tiga sub kebudayaan yang disebut sosio cultural types menjadi petani pedalaman Jawa dan Bali, masyarakat Islam Pantai, dan masyarakat pegunungan (Suryani, 2008: 3). Masyarakat Samin dengan ajaran sedulur sikep atau wong sikep adalah kelompok masyarakat yang mempercayai dan menganut ajaran dari pemimpin masyarakat Samin yaitu Samin Surosentiko (Purwasito, 2003: 16). Kata Samin sendiri berarti sami-sami amin (Purwasito, 2003: 16).

Ajaran Saminisme bermula dari kegelisahan Raden Surowijoyo yang tidak menyukai perilaku pemerintah Kolonial Belanda sebagai penjajah. Raden Surowijoyo kemudian melakukan sebuah gerakan moral dengan mengubah nama menjadi Samin (Sami-sami Amin yang berarti sama rata, sama sejahtera). Perubahan nama ini 
mencerminkan beliau sebagai wong cilik, dan dikemudian hari beliau terkenal dengan julukkan sebagai Samin Sepuh atau tetua adat dari masyarakat Samin.

Saminisme sebenarnya merupakan sebuah paham dari sejarah perlawanan terhadap kekuasaan Kolonial Belanda yang telah diubah menjadi deskripsi kebudayaan. Perlawanan terhadap Belanda dengan cara halus inilah yang dipakai oleh masyarakat Samin yaitu dengan menyebut mereka dengan sebutan sedulur sikep, hal ini menghapus anggapan buruk sebutan Samin di kalangan masyarakat yang belum mengetahui artinya, sedangkan sedulur sikep berasal dari kata sedulur atau wong yang berarti saudara atau orang sikep yang berarti tabiat atau watak yang jujur, baik, sehingga sedulur sikep berarti masyarakat atau saudara yang bertabiat baik serta jujur (Mumfangati, 2004:10).

Masyarakat Samin tidak menyukai pendidikan formal atau sekolah formal, di mana hal ini sering dianggap tidak lazim dalam pandangan masyarakat di luar warga Samin, apalagi di tengah kondisi seperti sekarang ini tidak menyekolahkan anak melalui lembaga formal adalah suatu hal yang aneh. Padahal menurut paham masyarakat Samin tidak menyukai pendidikan formal karena adanya kekhawatiran jika mendidik anak atau menyekolahkan anak pada pendidikan formal, maka anak akan belajar budaya lain dan meninggalkan komunitasnya atau masyarakatnya sehingga mengurangi kemurnian ajaran sedulur sikep.

Istilah budaya pop atau budaya populer saat ini merupakan lifestyle bagi sebagian besar masyarakat Indonesia karena budaya populer adalah budaya massa yang diproduksi massa untuk konsumsi massa seperti: pakaian, barang elektronik, perkembangan politik.

Hal yang menarik untuk terus ditelusuri adalah bagaimana manifestasi budaya pop atau budaya massa dalam keseharian masyarakat Indonesia kini. Diyakini bahwa budaya massa kini telah berkembang jauh dan pesat, menjangkau seluruh wilayah dan lapisan suku-suku bangsa di Indonesia yang mengalami persentuhan dengan teknologi informasi dan pusat perputaran barang dan jasa termasuk pada masyarakat Samin.

\section{Metode Penelitian}

Metode yang digunakan dalam penelitian ini menggunakan metode kualitatif dan Fenomenologi Edmun Hussrerl. Fenomenologi adalah objek ilmu yang tidak terbatas pada obyek yang bersifat empirik melainkan mencakup fenomena tentang persepsi, 
pemikiran, kemauan dan keyakinan obyek tentang sesuatu diluar obyek. Artinya melihat obyek penelitian ini tidak hanya terbatas pada data empirik tapi juga meliputi fenomena yang ada dalam obyek penelitian mencakup persepsi, pemikiran, kemampuan, dan keyakinan subyek penelitian yaitu masyarakat Samin di desa Klopoduwur.

\section{Pembahasan}

\section{Asal - usul Masyarakat Samin}

Kota Blora, Jawa Tengah terkenal karena terdapat suku Samin dengan ajaran sedulur sikep. Ajaran Samin yang terkenal di wilayah Blora dan sekitarnya tidak lepas dari sosok Samin Surosentiko. Samin Surosentiko merupakan keturunan dari Bupati Sumoroto di Jawa Timur yang bergelar Raden Mas Adipati Brotodiningrat yang berkuasa tahun 1802-1826

Raden Surowidjojo inilah yang menjadi cikal bakal masyarakat Samin. Nama kecil Raden Surowidjojo adalah Raden Surosentiko atau Suratmoko yang mengenalkan ajaran Samin. Kata Samin berasal dari kata dalam Bahasa Jawa sami-sami amin yang berarti sama-sama setuju, baik dan mendapat persetujuan dari masyarakat.

Pada 1890 Samin Surosentiko mulai mengembangkan ajarannya di desa Klopoduwur Blora Jawa Tengah. Masyarakat banyak yang tertarik dan dalam waktu singkat banyak orang menjadi pengikutnya. Pedoman ajaran Samin bersumber Kitab Jamus Kalimosodo yang ditulis oleh Raden Surowidjojo atau Samin Sepuh. Kitab Jamus Kalimosodo ditulis dengan bahasa Jawa baru serat macapat .

Pada tahun 1914 ini Samin Surosentiko meninggal dalam pengasingan di Sawah Lunto Sumatra Barat. Namun penangkapan terus dilanjutkan oleh pemerintah Belanda terhadap pengikut Samin. Walaupun perlawanan gerakan Samin terhadap pemerintah kolonial Belanda reda. Namun ajaran Samin tetap eksis hingga sekarang.

\section{Ajaran Samin}

Masyarakat Samin di Blora adalah salah satu suku yang ada di Indonesia. Masyarakat Samin merupakan keturunan dari Samin Surosentiko yang mengajarkan ajaran sedulur sikep. Ajaran ini bertujuan untuk mengobarkan semangat perlawanan terhadap Belanda tanpa kekerasan. 
Ajaran Sedulur sikep pertama kali diajarkan di daerah Klopoduwur Blora Jawa Tengah. Masyarakat Samin dengan ajaran sedulur sikep berkembang di dua desa di kawasan hutan Randublatung Blora Jawa Tengah. Ajaran dengan cepat menyebar ke desa-desa lainnya. Mulai dari pantai utara Jawa sampai seputar hutan di Pegunungan Kendeng Utara dan Kendeng Selatan di perbatasan provinsi Jawa Tengah dan Jawa Timur. Ajaran Samin yang disebut lebih dikenal dengan ajaran sedulur sikep mempunyai pokok ajaran sebagai berikut:

a. Agama adalah pegangan hidup. Masyarakat Samin tidak membeda-bedakan agama, oleh karena itu orang Samin tidak pernah mengingkari atau membenci agama lain. Yang penting adalah perilaku dan sikap hidup.

b. Jangan mengganggu orang lain, jangan bertengkar, jangan suka iri hati, dan jangan suka mengambil milik orang lain .

c. Bersikap sabar dan jangan sombong.

d. Manusia hidup harus memahami kehidupan sebab hidup adalah roh dan hanya ada satu, selamanya. Menurut masyarakat Samin, roh orang yang meninggal hanya menanggalkan pakaian atau badannya saja .

e. Bila berbicara masyarakat samin harus bisa menjaga diri, jujur, dan saling menghormati. Berdagang bagi masyarakat Samin dilarang karena dalam perdagangan terdapat ketidakjujuran contoh pada penentuan harga jual suatu barang. Masyarakat samin juga tidak boleh menerima sumbangan dalam bentuk uang.

\section{Kebudayaan Samin}

Masyarakat Samin sebagaimana masyarakat pada umumnya juga mempunyai paham yang dianggap oleh pendukungnya sebagai agama, masyarakat Samin memiliki pedoman hidup yaitu kitab Jamus Kalimosodo yang terdiri atas beberapa buku, antara lain Serat Punjer Kawitan, Serat Pikukuh, Serat Uiri-uri Pambudi, Serat Jati, Serat Sawit, Serat Lampaking Urip, dan serat-serat ini merupakan nama-nama kitab yang terkenal dan dimuliakan oleh masyarakat Samin.

Bahasa yang digunakan sehari-hari masyarakat samin adalah bahasa Jawa Ngoko, yaitu bahasa Jawa kasar. Pakaian yang dipakai oleh masyarakat Samin dalam keseharian terdiri dari baju lengan panjang tanpa krah warna hitam, celana selutut warna 
hitam dan memakai ikat kepala bagi laki-laki. Sedangkan para wanita memakai kebaya dan kain panjang.

Sistem kekerabatan masyarakat Samin mempunyai persamaan dengann sistem kekerabatan masyarakat Jawa pada umumnya. Tetapi masyarakat Samin tidak terlalu mengenal hubungan darah atau garis generasi di atas nenek dan kakek. Masyarakat Samin mempunyai tradisi berkunjung terutama pada saat tetangga mempunyai hajatan, mereka pasti datang walaupun jarak rumahnya sangat jauh.

Pernikahan dalam masyarakat Samin merupakan peristiwa yang sangat penting. Mereka tidak menikah di KUA atau Kantor Catatan Sipil tetapi di depan tetua adat. Kalau tetua adat tidak bisa datang maka perkawinan juga dianggap sah apabila dilakukan di depan orangtua kedua mempelai.

Ritual dan tradisi yang ada di masyarakat Samin antara lain nyadran, suran dan upacara yang berhubungan dengan daur hidup seperti khitanan, perkawinan, kehamilan,kelahiran, kematian yang biasanya dirayakan dengan sederhana.

\section{Masyarakat Samin dan Budaya Populer}

Perkembangan teknologi dan informasi yang memunculkan budaya populer juga mempengaruhi kehidupan masyarakat Samin. Hal ini dapat dilihat dari perilaku masyarakat Samin dalam keseharian, misal menggunakan peralatan plastik, alumunium untuk peralatan dapur, menggunakan pupuk buatan paprik untuk bertani, mempunyai peralatan elektronik seperti HP, TV, Radio, tape. Bahkan ada beberapa masyarakat Samin yang mempuntai sepeda motor, mobil.

Masyarakat Samin bisa menerima hadirnya budaya populer dan perkembangan teknologi informasi. Tetapi masyarakat Samin tetap menjaga kemurnian ajaran sedulur sikep. Misalnya mereka bisa menerima hadirnya hand phone tetapi HP hanya sebatas alat merek tetap berkomunikasi dengan bahasa Jawa ngoko tidak memilih menggunakan bahasa populer, hal ini juga dilakukan oleh pemuda-pemudi suku samin.

Masyarakat samin merupakan masyarakat yang dapat memadukan masuknya budaya populer dengan sikap dan ajaran sedulur sikep. Ajaran sedulur sikep pada masyarakat samin tetap bertahan sesuai dengan porsinya walaupun kebudayaan populer masuk keranah kehidupan masyarakat samin. Misalnya saat ini masyarakat Samin sudah ada yang sekolah bahkan ada yang kuliah di UMK ( Universitas Muria Kudus) tetapi 
dalam keseharian mereka tetap memakai pakaian khas suku samin, berbahasa Jawa, dan tetap sebagai penganut kepercayaan.

Masyarakat Samin adalah komunitas yang konsisten dalam berperilaku antara lain menjunjung tinggi nilai kejujuran, tidak iri, dengki, tidak berprasangka jelek pada orang lain, bersikap dan bertindak apa adanya .Bagi mereka yang terpenting adalah bersikap jujur dan tidak mengganggu orang lain dan sebaliknya merekapun tidak mau orang lain mengganggu kehidupan mereka. Dalam kehidupan sehari-hari masyarakat Samin memegang teguh ajaran Saminisme yang sudah mengakar. Masyarakat Samin berusaha menjaga eksistensi dan memelihara kebudayaan serta ajaran sedulur sikep dengan menanamkan dan mengajarkan pada keturunan dan generasi muda suku samin

Penduduk desa Klopoduwur yang sebagian besar keturunan Samin pada mulanya tidak mempunyai agama, mereka menganut paham kepercayaan, di mana masyarakat Samin menyebut sebagai agama Adam. Orang Samin saat ini menganut agama yang disahkan pemerintah, alasan pemilihan agama seperti ini ternyata diikuti oleh anak-anak keturunan masyarakat Samin, mereka memilih agama Islam agar mereka sama dengan masyarakat pada umumnya dan bisa membuat KTP. Tetapi masyarakat Samin tidak berani meninggalkan keperayaan pendahulunya.

Kesadaran berorganisasi dalam masyarakat Samin mulai terlihat. Hal ini dibuktikan masyarakat Samin mengajak petani dari desa sekitar untuk membentuk kelompok tani. Mereka juga menggunakan peralatan pertanian modern seperti traktor, dan pupuk buatan.

Masyarakat Samin adalah masyarakat yang menjunjung tinggi nilai-nilai ajaran dari para pendahulunya. Memang sekarang ini masyarakat Samin sudah banyak yang berubah pola pikirnya terutama mengenai pendidikan, khususnya mengenai pendidikan anak, mereka membiarkan anak-anak belajar bermain seperti anak-anak pada umumnya, tetapi mereka sendiri tetap berpegang pada ajaran Samin.

Masyarakat Samin adalah komunitas yang konsisten dalam berperilaku antara lain menjunjung tinggi nilai kejujuran, tidak iri, dengki, tidak berprasangka jelek pada orang lain, bersikap dan bertindak apa adanya. Budaya Samin atau Saminisme sebagai sikap dan kepercayaan masyarakat memang tidak banyak memberi peluang untuk masuknya dan tumbuhnya budaya baru di masyarakat. Paham itu memang 
mengecualikan kemungkinan bertumbuhnya kebudayaan dan kercayaan baru di masyarakat Samin..

Masyarakat Samin adalah masyarakat yang menjunjung tinggi nilai-nilai ajaran dari para pendahulunya. Walaupun sekarang ini masyarakat Samin sudah banyak yang berubah polapikirnya terutama mengenai pendidikan, masyarakat Samin saat ini membiarkan anak-anak mereka belajar dan bersekolah seperti masyarakat pada umumnya, akan tetapi masyarakat Samin tetap berpegang pada ajaran Samin yaitu sedulur sikep.

Perilaku kehidupan masyarakat Samin sangat berbeda dengan masyarakat lainnya, bahkan berbeda dengan masyarakat suku Jawa sendiri, hal ini dapat dilihat dari tatacara, adat-istiadat, dan kepercayaan. Masyarakat Samin menganut ajaran kesederhanaan hidup, seperti pakaian sederhana warna hitam, celana komprang juga berwarna hitam, bertutur bahasa dengan lugas dan lugu yang tidak banyak bercampur bahasa daerah lain.

Masyarakat Samin adalah komunitas yang konsisten dalam berperilaku antara lain menjunjung tinggi nilai kejujuran, tidak iri, dengki, tidak berprasangka jelek pada orang lain, bersikap dan bertindak apa adanya (tidak mengada-ada). Bagi masyarakat Samin yang penting tidak mengganggu orang lain dan sebaliknya masyarakat Samin juga tidak mau orang lain mengganggu kehidupan dan pranata sosialnya.

Menurut ajaran Samin orang harus rajin bekerja, mencintai alam semesta, jangan mencuri milik orang lain dan apabila ada seseorang minta sesuatu barang milik orang lain, maka orang itu wajib memberikan. Dalam kehidupan sehari-hari masyarakat Samin memegang teguh ajaran Samin yang sudah mengakar, mereka berusaha mempertahankan, memahami dan memelihara kebudayaan masyarakat dengan menumbuhkan dan mengajarkannya pada generasi muda di masyarakat Samin.

Sebagaimana anak-anak pada umumnya putra-putri masyarakat Samin juga bersekolah hanya supaya bisa membaca dan menulis, akan tetapi perkembangan pendidikan baik pendidikan agama atau pendidikan yang lainnya kurang menggembirakan, hal ini terjadi karena tidak adanya dorongan atau motivasi dari para orang tua pada anaknya untuk belajar baik agama maupun yang lain, bahkan sebagian masyarakat Samin keberatan kalau anak-anaknya memperoleh pendidikan agama seperti 
mengaji, alasannya pendidikan agama akan melarang, menentang dan menghilangkan ajaran dari kepercayaan masyarakat.

Budaya Samin atau Saminisme sebagai sikap dan kepercayaan masyarakat memang tidak banyak memberi peluang untuk masuknya dan tumbuhnya budaya baru di masyarakat. Paham itu memang mengecualikan kemungkinan bertumbuhnya kebudayaan dan kercayaan baru di masyarakat Samin..

Masyarakat Samin adalah masyarakat yang menjunjung tinggi nilai-nilai ajaran dari para pendahulunya. Walaupun sekarang ini masyarakat Samin sudah banyak yang berubah polapikirnya terutama mengenai pendidikan, masyarakat Samin saat ini membiarkan anak-anak mereka belajar dan bersekolah seperti masyarakat pada umumnya, akan tetapi masyarakat Samin tetap berpegang pada ajaran Samin yaitu sedulur sikep. Eksistensi ajaran sedulur sikep pada masyarakat Samin terjadi karena kuatnya masyarakat menjaga adat dan pesan leluhur. Masyarakat Samin sangat menjunjung tinggi kejujuran, kebaikan, ketradisionalan mereka. Inilah yang membuat masyarakat Samin sebagai suku bangsa yang unik.

\section{Kesimpulan}

Masyarakat Samin di Blora merupakan salah satu suku bangsa yang ada di Indonesia. Masyarakat Samin merupakan keturunan dari Samin Surosentiko yang mengajarkan ajaran sedulur sikep. Ajaran ini bertujuan untuk mengobarkan semangat perlawanan terhadap Belanda tanpa kekerasan. Bentuk yang dilakukan adalah menolak membayar pajak, dan segala peraturan yang dibuat pemerintah kolonial Belanda . Masyarakat Samin seringkali membuat pusing pemerintah Belanda maupun Jepang karena sikap samin yang hingga sekarang dianggap menjengkelkan bagi masyarakat luar.

Masyarakat Samin adalah komunitas yang konsisten dalam berperilaku antara lain menjunjung tinggi nilai kejujuran, tidak iri, dengki, tidak berprasangka jelek pada orang lain, bersikap dan bertindak apa adanya (tidak mengada-ada). Bagi masyarakat Samin yang penting tidak mengganggu orang lain dan sebaliknya masyarakat Samin juga tidak mau orang lain mengganggu kehidupan dan pranata sosialnya Masyarakat Samin bisa menerima hadirnya budaya populer dan perkembangan teknologi informasi. Tetapi masyarakat samin tetap menjaga kemurnian ajaran sedulur sikep. 


\section{Daftar Pustaka}

Atmodjo, RPA Soerjanto Sastro. 2003. Masyarakat Samin Siapakah Mereka. Yogyakarta: Penerbit Narasi.

Fiske, John. 1989. Understanding Popular Culture. London: Unwin Hyman.

Maltby, Richard. 1989, "Introduction" dalam Dreams for Sale: Popular Culture in the 20th Century, disunting oleh Richard Malthy. London: Routledge.

Ross, Andrew, 1989, No Respect: Intelectuals and Popular Culture. London: Routledge.

Sadi Hutomo. 1996. Tradisi Dari Blora. Semarang : Penerbit Citra Al Mamater,

Siregar dan Wahono. 2002. Kembali Ke Akar. Jakarta: Forum Pengembangan Partisipasi Masyarakat.

Subangun, Emmanual. 1994. Dari Saminisme ke Posmodernisme. Yogyakarta: Cri Alocita.

Lembaran Daerah Kabupaten Daerah Tingkat II Blora. 